\title{
Mapping the Water Usage Behaviour of Presto Milkfish Processing Industries in Semarang City
}

\author{
Novie Susanto ${ }^{1, *}$, Thomas Triadi Putranto ${ }^{2}$, Heru Prastawa ${ }^{1}$ \\ ${ }^{1}$ Industrial Engineering Department, Faculty of Engineering, Diponegoro University, Semarang - Indonesia \\ ${ }^{2}$ Geological Engineering Department, Faculty of Engineering, Diponegoro University, Semarang - Indonesia
}

\begin{abstract}
Water is one of the natural resources that play an important role in the field of industry. Milkfish fish processing industries is leading commodity of Semarang City that roles as important stakeholder related to both groundwater and PDAM consumer. The demand of clean water supply quite a lot. This have impact on the utilization of groundwater as the main raw material or auxiliary materials in the production process with considerable capacity such as fish washing process, flavoring, steaming process on peresto equipment and cleaning equipment. They should be studied the ecological behavior related to water condition. This study aims to map milkfish processing process based on water use by distinguishing traditional and modern processing systems. The research method used is field work and water footprint. The number of respondents in this research is 5 milkfish processing industries in Semarang City. Research is conducted by analyzing the processing and water needs for each stage of the process. The results showed that water use amounted to 59-149 litters with the most use in cleaning equipment process. Production capacity of processing industry varies from $10-100 \mathrm{~kg}$. The results are used as redesign material of the process to optimize water use in industry.
\end{abstract}

Keywords: milkfish, Semarang, water usage, behaviour

\section{Introduction}

Presto milkfish processing industry is one of the industries that diverse milkfish product based on the process. It increases the selling value of fish and absorb a lot of manpower. Presto milkfish processing industry divide into small scale, medium scale and large scale. The small scale is intended for sidewalk business that usually only produce about $10-25 \mathrm{~kg}$ /day depend on demand from customers. There is also medium scale that reach $30-75 \mathrm{~kg} /$ day and large scale that can produce about $100-200 \mathrm{~kg} /$ day. Indonesia is a breeding area of milkfish covering the eastern region of Sumatra, Java, Kalimantan, Sulawesi, Maluku, Papua, Bali and Nusa Tenggara.

The development of fish processing industry in Semarang city becomes one of important factor which drives the regional economy wheel. One of the potential industries in Central Java, especially in Semarang City is milkfish presto processing industry. The strategic location of Semarang City which is at the center point of the main route of North Beach of Java Island makes this city more developed as a potential area for highly prospective industrial, trading and service activities. Similarly, the potential of fishery resources large enough to be developed. Processed fish is quite important in the city of Semarang and became one of the typical souvenir products Semarang. The example is processed milkfish with a variety of product diversification such as presto milkfish. Presto milkfish is a fish-boneless processed milkfish that formed by cooking at high temperatures in the long term.

Presto milkfish processing industry is one of industry that needs clean water supply quite a lot. This will have an impact on the utilization of groundwater as the main raw material or auxiliary materials in the production process with considerable capacity such as for fish washing process, seasoning, steaming process on presto equipment and cleaning equipment. Form of pollution arising and complained by the community due to milkfish presto processing industry is groundwater and surface water pollution, air pollution in the form of odor from residual water fish laundry and steaming, changes in allotment of water bodies (especially river water for the needs of bathing, drinking and cultivation water biota), mass death of aquaculture biota (fish and shrimp), conflicts of interest and other forms of pollution. A good quality waste can be utilized as food for human, while waste with decreasing quality can only be used as animal feed. Waste that has been decomposed can not be utilized so that it can become pollutant to the environment [1].

\footnotetext{
* Corresponding author: novie.susanto@ft.undip.ac.id
} 
Previous studies have addressed human ecological behavior regarding the use of groundwater conservation and susceptibility [2,3] and the role of stakeholders related to groundwater management [4]. This study focuses on monitoring the impact of industrialization in a broader context through the ecological behavior of milkfish processing industries related to the use and management of groundwater using the Water Footprint method. The water footprint concept (WF) was introduced in 2002 by Hoekstra [5-7]. WF is an indicator of water use by consumers or producers either directly or indirectly. The purpose of the WF assessment is to analyze the specific human or product activities related to water pollution issues and to assess how activities and products can be more sustainably viewed from a water perspective. WF is defined as the total volume of water used to produce goods and services for consumption by individuals or communities [6]. Recent studies related waterfootprint is mostly conducted such as by [8-14].

\section{Methods}

The research is performed in descriptive form with quantitative and qualitative approach. Quantitative approach is used to calculate emission value and waste of milkfish product presto, while qualitative approach is used to analyze the result of data processing so that it can be given appropriate recommendation for related stakeholders. The data collected in this study is the primary data. Data collection is conducted by direct observation to field and interview. Data or information collected related to the water needs, production process, and waste produced in the production of milkfish presto from some Presto milkfish processing industry in Semarang City. Interview conducted to the owner of Presto milkfish processing industry and also the workers.

Total industries participated in this study is 5 processing industry of milkfish presto consisting of large industry, middle industry and small industry with continuous production system. Presto milkfish processing is divided into two, namely traditional and modern. Data is obtained by interview and direct observation on milkfish processing industry in Semarang City. The study started with mapping of milkfish industry in Semarang City, followed by data collection related to water source, processing system, processing process, amount of water use and production capacity. This study used Waterfootprint method by using Simapro 8.5 to estimate the volume of water used in presto milkfish production process. Table 1 shows data that will be required for this study. However, producers of milkfish presto mostly found in Krobokan Village, West Semarang District. Presto milkfish industry is dominated by business units belonging to home and small industries.

\section{Result and Discussion}

\subsection{Mapping of Milk Industry Characteristics}

In Semarang, there are more than 44 processing industries that produce milkfish presto spread in $14 \mathrm{sub}$ districts and 25 urban villages [15].

Table 1. Data collection

\begin{tabular}{|l|l|l|}
\hline \multicolumn{1}{|c|}{ Input } & Output & $\begin{array}{l}\text { Data } \\
\text { Retrieval } \\
\text { Techniques }\end{array}$ \\
\cline { 1 - 2 } $\begin{array}{l}\text { Total Waste Water Volume } \\
\text { (Liter) }\end{array}$ & $\begin{array}{l}\text { Impact } \\
\text { score }\end{array}$ & $\begin{array}{l}\text { Interview and } \\
\text { observation }\end{array}$ \\
\cline { 1 - 2 } $\begin{array}{l}\text { Number of Water Volume } \\
\text { (Liter) }\end{array}$ & & \\
\cline { 1 - 2 } $\begin{array}{l}\text { Water Volume at Water } \\
\text { Source (Liter) }\end{array}$ & & \\
\cline { 1 - 2 } $\begin{array}{l}\text { Water Volume for Dilution } \\
\text { of Waste (Liter) }\end{array}$ & & \\
\cline { 1 - 2 } $\begin{array}{l}\text { Water requirement by } \\
\text { Environment (Liter) }\end{array}$ & & \\
\hline
\end{tabular}

In the presto milkfish industry, the characteristics of producers (craftsmen) are implicitly related to the amount of milkfish processed per day. These characteristics vary from the scale of business, production, labor, facilities owned, how to obtain raw materials, product marketing and others

Based on the observations, there are several types of water sources, processing systems and processing process found in milkfish processing industry in Semarang City. Water sources can be divided into 3 types: PDAM, ground water wells and purchases of mountain water. The processing system is divided into two kinds, namely modern and traditional. Processing differs depending on the processing system used by each industry. The diagram of each processing process can be seen in Figures 1 and 2.

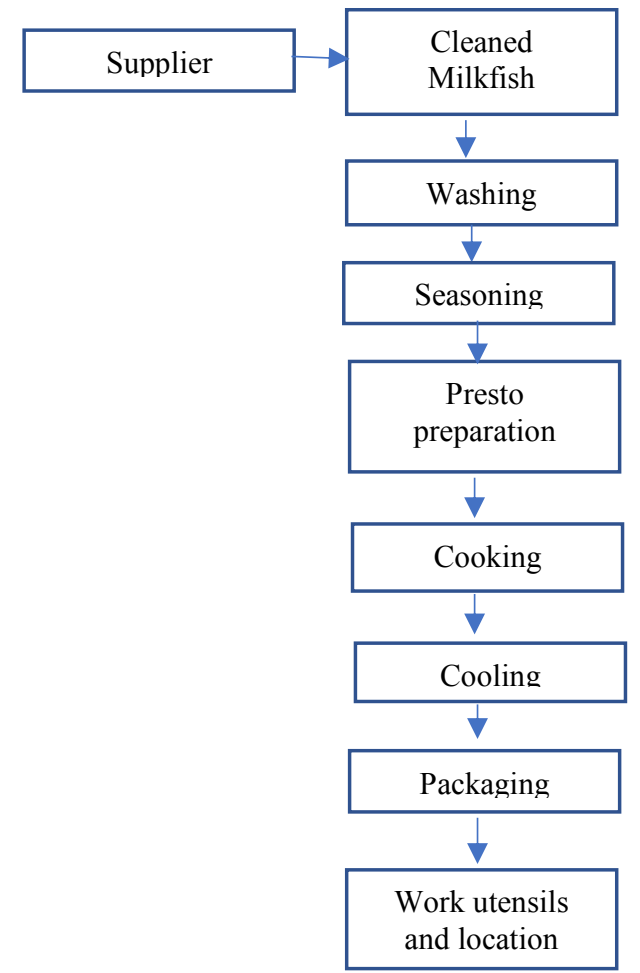


Fig. 1. Process of milkfish with modern system

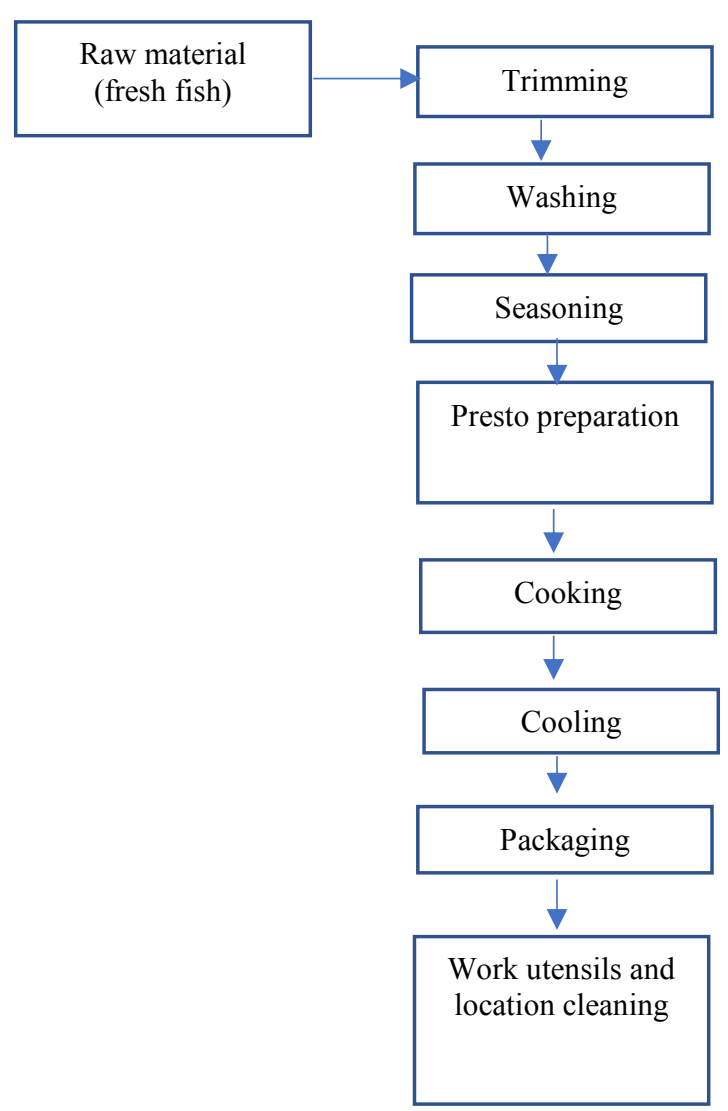

Fig. 2. Process of milkfish with traditional system

Traditional process requires lot of clean water because the raw material (milkfish) is fresh fish from the market that have not been cleaned. In modern processing milkfish, they use autoclave tool and the raw materials from the market has been cleaned. By doing so, it only needs few amounts of water. Traditional processing for large scale industries can be seen in Fig. 3.

\subsection{Mapping of Behavior of Water Utilization of Milkfish Industry}

Based on observations, the use of water in the milkfish industry will depend on the system and processing process undertaken. Data from the research sample can be seen in Table 2.

\subsection{Water Footprint}

The calculation is performed based on the input of the amount of water required for presto milkfish processing. Waterfootprint calculation is conducted by using software Simapro 8.5 with model of Hoekstra et al. (2012) (Water Scarcity). The result for each industry can be seen in Table 3.

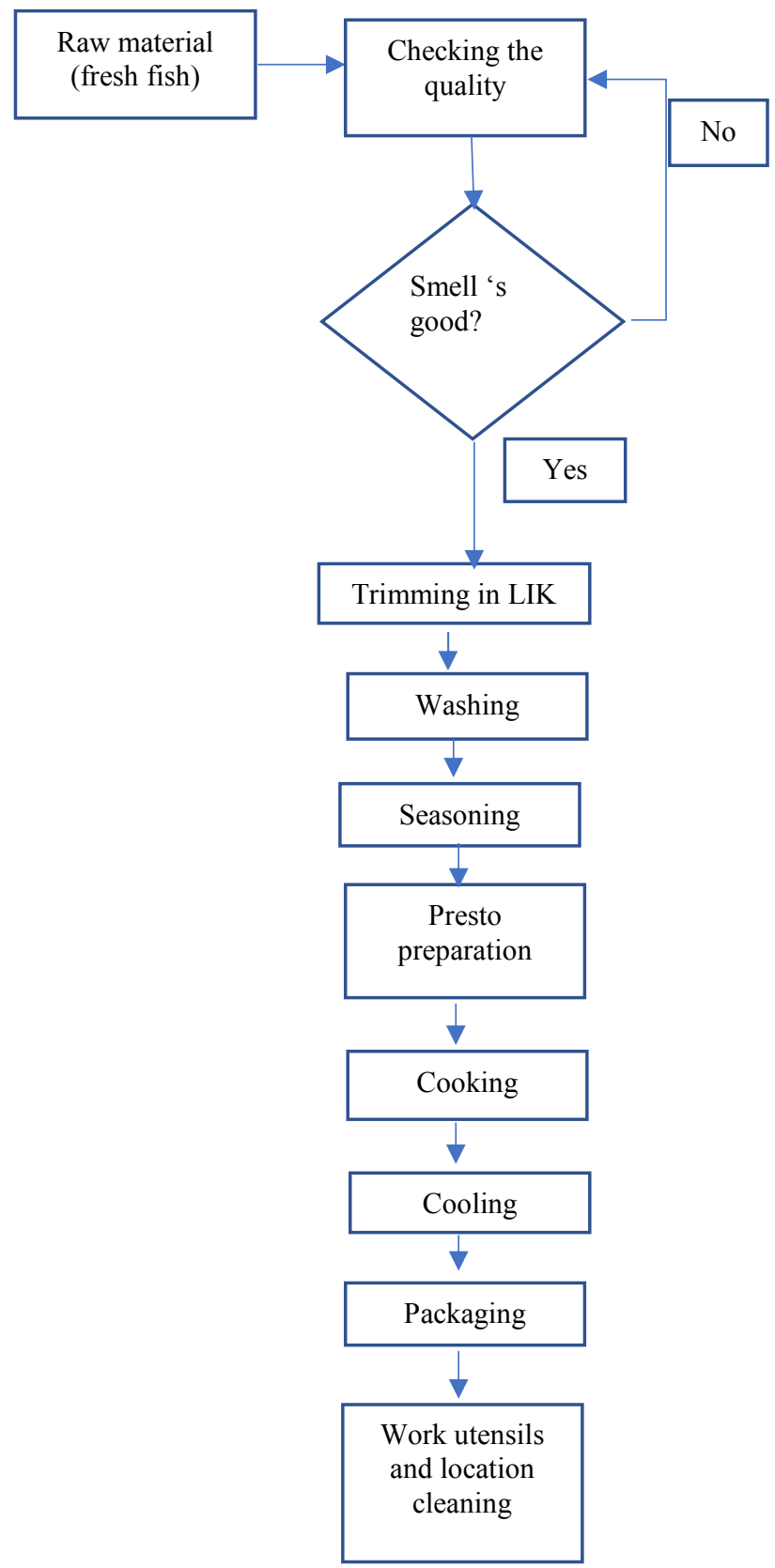

Fig. 3. Milkfish processing process with modern system for large scale industry.

Based on Waterfootprint calculation using Simapro software, it is obtained that industry Traditional 1 achieves the greatest value $(3.85 \mathrm{~m} 3$ per month) and Modern 2 gained $3.63 \mathrm{~m} 3$ per month. The traditional process requires more clean water due to the need of cleaning process inside the raw materials of milkfish. Table 3 shows the output weighting of milkfish processing. 
Table 2. Water requirements for each type of processing

\begin{tabular}{|c|c|c|c|}
\hline & $\begin{array}{l}\text { Production } \\
\text { capacity }\end{array}$ & Activity & $\begin{array}{l}\text { Water } \\
\text { usage } \\
\text { (litters) }\end{array}$ \\
\hline \multirow[t]{4}{*}{ Modern 1} & $10 \mathrm{~kg} /$ day & Washing & 25 \\
\hline & & Seasoning & 1 \\
\hline & & $\begin{array}{l}\text { Presto } \\
\text { preparation }\end{array}$ & 3 \\
\hline & & Cleaning & 30 \\
\hline \multirow[t]{4}{*}{ Modern 2} & $25 \mathrm{~kg} /$ day & Washing & 60 \\
\hline & & Seasoning & 2 \\
\hline & & $\begin{array}{l}\text { Presto } \\
\text { preparation }\end{array}$ & 5 \\
\hline & & Cleaning & 40 \\
\hline \multirow[t]{4}{*}{ Traditional 1} & $15 \mathrm{~kg} /$ day & Washing & 70 \\
\hline & & Seasoning & 2 \\
\hline & & $\begin{array}{l}\text { Presto } \\
\text { preparation }\end{array}$ & 5 \\
\hline & & Cleaning & 50 \\
\hline \multirow[t]{4}{*}{ Traditional 2} & $35 \mathrm{~kg} /$ day & Washing & 60 \\
\hline & & Seasoning & 3 \\
\hline & & $\begin{array}{l}\text { Presto } \\
\text { preparation }\end{array}$ & 5 \\
\hline & & Cleaning & 50 \\
\hline \multirow[t]{4}{*}{$\begin{array}{l}\text { Modern } 3 \\
\text { (large scale) }\end{array}$} & $\begin{array}{l}100 \\
\mathrm{~kg} / \text { day }\end{array}$ & Washing & 80 \\
\hline & & Seasoning & 4 \\
\hline & & $\begin{array}{l}\text { Presto } \\
\text { preparation }\end{array}$ & 5 \\
\hline & & Cleaning & 60 \\
\hline
\end{tabular}

\subsection{Design of Intervention model for Water Usage Optimization in Milkfish Processing.}

Based on interview and discussion with the expert, it is concluded that there are some designed interventions for optimizing the water consumption in presto milkfish processing. The first intervention is differing the modern and traditional process and directed the traditional system to adopt the low-cost modern processing system. Besides, some facilities, tools and training should be performed to educate the worker about the water usage optimization. Figure 4 show the intervention model of water usage in presto milkfish processing.

Table 3 Output Weighting of Milkfish processing

\begin{tabular}{|c|c|}
\hline Impact Category $:$ WSI & Unit (m3) \\
\hline Traditional 1 & 3.85 \\
\hline Traditional 2 & 3.25 \\
\hline Modern 1 & 2.29 \\
\hline Modern 2 & 3.63 \\
\hline Modern 3 & 2.47 \\
\hline
\end{tabular}

\section{Conclusion and Further Studies}

The results showed that there are two kinds processing system in milkfish processing. They are: modern and traditional. There are three water sources that used for processing: PDAM, mountain water and groundwater wells. The water use amounted to 59-149 litters with the most use in cleaning equipment process. Production capacity of processing industry varies from $10-100 \mathrm{~kg}$.

The topic for futher study is the implementation of the intervention model implementation and evaluation of the results of the implementation of the model. Besides, to validate the model, it can also applied in other SMEs such as batik, fish proceesing, or others.

\section{Acknowledgement}

This research was financially supported by Direktorat Riset dan Pengabdian Masyarakat, Direktorat Jenderal Penguatan Riset dan Pengembangan, Kementrian Riset, Teknologi dan Pendidikan Tinggi in PDUPT 2018 scheme.

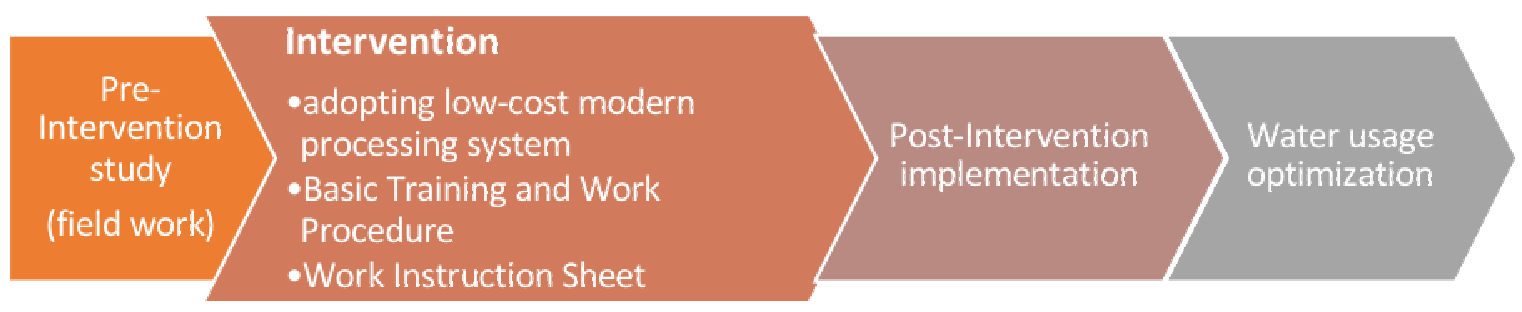

Fig. 4. Intervention model of water usage in presto milkfish processi 


\section{References}

1. U.N. Mahida. Pencemaran Air dan Pemanfaatan Limbah Industri. Jakarta: Rajawali (1986).

2. N. Susanto, T.T. Putranto dan D. Widiarso. Preliminary Study of the Human Activities and Perception on the Groundwater Vulnerability: A Report from Lowland Areas of Semarang City. MATEC web of conference 101. 04003. 2017 from SICEST 2016 (2017)

3. T.T Putranto, D.A. WIdiarso and N. Susanto. Assessment of Groundwater QUality to Achieve Sustainable Development in Semarang Coastal Area. IOP Conferences Series: Earth and Environmental Science 79(1), 012001 (2016).

4. N. Susanto and T.T Putranto. Int. J. of GEOMATE. JULY, 2018. 15(47) 170-177. (2018).

5. A. Y. Hoekstra and P.Q. Hung 'Virtual water trade: A quantification of virtual water flows between nations in relation to international crop trade', Value of Water Research Report Series No. 11, UNESC0IHE Institute for Water Education, Delft, the Netherlands. http://www.waterfootprint.org/Reports/Report1 1.pdf (2002).

6. A. K. Chapagain and A.Y. Hoekstra 'Virtual water flows between nations in relation to trade in livestock and livestock products', Value of Water Research Report Series No. 13, UNESC0-IHE, Delft, the Netherlands.

http://www.waterfootprint.org/Reports/Report1 3.pdf (2003) .

7. A.Y. Hoekstra, A.K, Chapagain, M.M Aldaya, and M.M. Mekonen. The Water Footpint Assessment Manual: Setting the Global Standard. Earthscan, London, UK (2011).

8. J. Sorvari, P. Porvari and S.Koskela. Survey on the environmental efficiency assessment methods and indicators. MMEA Research Report nr D2.1.1. Cleen Ltd. Helsinki (2012).

9. L.D.Benedetto and J. Klemes. The Environmental Performance Strategy Map: an integrated LCA approach to support the strategic decision-making process (2009).

10. M. Berger and M.Finkbeiner. Sustainability 2, 919-944 (2010).

11. D. Jefferies, I. Munoz, J. Hodges, V.J. King, M. Aldaya, A.E. Ercin, L. Mila, and A.Y. Hoekstra. Journal of Cleaner Production 33, 155-166. (2012).

12. V. Kountantelia and M. Papadopoulo, Environmental Impact Assessment of an Industrial Activity based on Life Cycle Analysis and Water Footprint Concept. Proceeding of International Conference Win4Life. September 19-21, 2013. Tinos Island, Greece (2013).

13. S. Sala, A. Bianchi, J.C. Bligny, F. Bouraoui, V. Castellani, C. De Camillis, S. Mubareka, I., Vandecasteele and M.A Wolf. Water fooprint in the context of sustainability assessment. JRC scientific and policy report. Luxemburg: Publication Office of the Europian Union (2012).

14. S.A. Munro, G.C.G. Fraser, J.D. Snowball, M. Pahlov. Water Footprint Assessment of Citrus Production: A Case Study of the Lower Sundays River Valley. Journal of Cleaner Production. South Africa: Department of Economics and Economic History Rhodes University (2016).

15. Badan Pusat Statistik Kota Semarang, 2015. Kota Semarang dalam angka (2015).

*Corresponding author: novie.susanto $@$,ft.undip.ac.id 